Revista do CESP, Belo Horizonte, v.36, n.55, p. 129-131, 2016

\title{
TAVARES, Gonçalo M. Os velhos também querem viver. Rio de Janeiro: Foz, 2014.
}

Roberto Bezerra de Menezes

Universidade Federal de Minas Gerais (UFMG), Belo Horizonte, Minas Gerais, Brasil robertobmenezes@gmail.com

Data de recebimento: 7 de julho de 2016

Data de aprovação: 18 de setembro de 2016

Os velhos também querem viver, novela-poema de Gonçalo $\mathrm{M}$. Tavares, é mais um caso da relação do escritor com a tradição e o passado literário. Alocado na série Estudos Clássicos, junto a Histórias falsas, de 2005, o texto se põe a atualizar a conhecida tragédia Alceste, de Eurípides.

Cultuado tanto pelo número de livros publicados num curto espaço de tempo quanto pela qualidade literária, Gonçalo M. Tavares não teve, no livro em questão, unanimidade positiva da crítica especializada. Isso se deve, em parte, à expectativa em torno de um escritor em íngreme ascensão; mas também pela relativa simplicidade de sua proposta de releitura do clássico grego, visto que o conflito humano, como é posto por Eurípides, se mantém, ocorrendo muito mais um deslocamento no tempo e no espaço, agora modernos.

Escritor de variados gêneros, como a ficção, o romance, o teatro, o ensaio e a poesia, para além das categorias e nichos específicos criados pelo autor, Os velhos também querem viver é classificado como ficção, a despeito de sua estrutura estar toda em verso, mesmo o prólogo e o epílogo. Além da abertura e do fechamento, o livro conta com cinco capítulos curtos.

Convém recapitular a história de Alceste, esposa de Admeto, rei de Feras, no ponto em que interessa a Tavares: o rei só pode salvar-se da 
morte se alguém sacrificar-se em seu lugar, o que só é prontamente feito por sua esposa, Alceste, ato nem mesmo cogitado pelo seu pai ou amigos. Diante da troca e da morte iminente de Alceste, em sacrifício pela vida do marido, o herói Hércules intervém e salva Alceste da morte, agindo como deus ex machina. Na releitura de Tavares, o gesto de sacrifício se mantém e o ambiente é o da guerra em Sarajevo, nos anos 1990: "Um sniper atingiu Admeto; Admeto está a morrer. / Sabe que poderá ser salvo apenas / se alguém morrer em sua vez; todos recusam exceto / a mulher, Alceste. / Alceste morrerá para que Admeto possa ficar vivo. / É esta a história." (TAVARES, 2014, p. 7).

A discussão que Gonçalo M. Tavares propõe passa pelo valor da vida em um ambiente em guerra, onde morrer é apenas uma probabilidade cada vez mais iminente. Nesse ambiente, de que vale discutir a vida, afinal? Esse ponto é exposto no confronto entre Admeto e seu velho pai, Feres, que inspira o título da obra. Admeto, ao criticar a postura do pai na escolha pela conservação da própria vida em detrimento da salvação do filho, recebe do pai a argumentação acerca do valor da vida, em especial da vida do velho em sociedade, que associa diretamente à sabedoria:

[...] Que a vida não é, diz Feres,

um cálculo simples, numérico e quantitativo.

Se os novos gostam de viver, os velhos também.

E por que razão a vida de um velho valeria menos

do que a vida de alguém que agora começa?

Que cálculos absurdos são esses? murmura.

E por que não o contrário?

Por que não proteger a sabedoria dos muitos anos, em vez da excitação do jovem que ainda quer conhecer?

Sou velho, diz Feres, e por isso quero viver!

E tu, Admeto, és novo e por isso queres viver!

Pois bem: os dois queremos o mesmo, apesar da diferença de idade. Não podes pensar que um velho é metade de um homem; um velho como eu é pelo menos dois homens, eu diria, pela experiência, pela sabedoria. (TAVARES, 2014, p. 54)

Refletir sobre o valor da vida em plena guerra é a estratégia do autor para aproximar duas tragédias, reunidas no tempo suspenso da literatura. Nesse ponto, vale retomar a pergunta de Hölderlin, na elegia "Pão e vinho": "O que esperar, que fazer entrementes, ou o que dizer? / 
Não sei: e para que poetas num tempo de indigência?" (HÖLDERLIN, 1991, p. 171), ecoada por Hélia Correia, a quem Tavares dedica o livro: "Para quê, perguntou ele, para que servem / Os poetas em tempo de indigência?" (CORREIA, 2012, p. 7). Os tempos sombrios, aqui representados pela guerra e pelas falhas morais, são parte do elo que mantém acesa a inspiração nos textos de outrora, gesto comum tanto em Hélia Correia quanto em Gonçalo M. Tavares. Tal dedicatória parece revelar a afinidade possível entre a releitura de Alceste, por Tavares, e as releituras empreendidas por Correia, em especial os exercícios dedicados a pensar, no teatro, as figuras Antígona e Helena, além de A terceira miséria, que reflete sobre as ruínas do mundo e a ruína simbólica do ocidente.

Quanto à obra de Tavares, cumpre ainda ressaltar que sua sustentação advém da diferença entre a visão de mundo na antiguidade clássica e o mundo moderno. Sublinhamos, aqui, as posturas pouco sacralizadas dos deuses e semideuses, como é o caso de Hércules, que comete uma "falha moral" (2014, p. 69) ao festejar na casa de Admeto durante seu luto. Nesse momento, presenciamos o rebaixamento da figura do herói, "alegre mas distraído" (2014, p. 65), pouco crível no mundo moderno. Essa desconfiança é marcada pela voz do narrador moderno, que assume tal sentimento no momento em que decide não acompanhar a façanha de Hércules para reaver Alceste do mundo dos mortos: "O narrador moderno, esse, não acredita; / Hércules sai e vai confiante; / o narrador fica." (2014, p. 73).

Ainda que a releitura de textos antigos transpostos para o presente não seja de modo algum original, a experiência de Tavares, que já ousou inclusive fazer um movimento parecido com Os Lusíadas, de Camões, em Uma viagem à Índia (2010), por exemplo, ganha contornos pertinentes ao propor reflexões morais para o mundo atual, fazendo uso do passado para pensar o mundo presente.

\section{Referências}

CORREIA, Hélia. A terceira miséria. Lisboa: Relógio D’Água, 2012.

HÖLDERLIN, Friedrich. Poemas. Seleção, tradução e introdução de José Paulo Paes. São Paulo: Companhia das Letras, 1991.

TAVARES, Gonçalo M. Os velhos também querem viver. Rio de Janeiro: Foz, 2014. 